\title{
Anatomical and morphological copper provision indexes in wheat (Triticum aestivum L.)
}

\author{
ELŻBIETA WERYSZKO - CHMIELEWSKA
}

Department of Botany, Institute of Natural Principles of Plant Production, Agricultural Academy, Akademicka 15, 20-934 Lublin, Poland

(Received: May 12, 1989)

\begin{abstract}
The morphology and anatomy of wheat (Triticum aestivum L.) stems under conditions of copper deficiency were investigated. Copper was supplied at 0,5 and $125 \mathrm{mg}$ per Mitscherlich pot. The lignification of tissues in plants from field experiments $(0 ; 5 ; 10 ; 20 \mathrm{mg} \mathrm{Cu} / \mathrm{ha})$ was also studied. Significant changes in stem and leaf morphology and anatomy were found along inhibition of inflorescence and flower development. The anthers produces sterile and deformed pollen grains. The diminished stability of stems was caused by the following anatomical changes: considerable reduction of steam diameter and culm wall thickness and decreased numbers and dimensions of sclerenchyma and parenchyma cells and layers. In addition, the size of vascular bundles and the diameter of xylem vessels were decreased and the sclerenchyma sheath around the vascular bundles was reduced. The epidermis and sclerenchyma cells had thinner walls. The absence of lignification of cells walls was observed most frequently in the peripheral tissues (epidermis, sclerenchyma and parenchyma). It was demonstrated that it was possible to histochemically determine the degree of stem lignification in the early phases of wheat development.
\end{abstract}

\section{INTRODUCTION}

Copper is one of the elements that is poorly transported in plants. A deficiency of this element may occur in peat and sandy soils as well as in intensively cultivated soils of other types due to improper fertilization and an unfavorable $\mathrm{Cu}: \mathrm{N}$ balance.

The first symptoms of $\mathrm{Cu}$ deficiency are observed in the apical, intensively growing parts of plants - the youngest leaves, which wither, dry up and die and in shoot apexes, which are characterized by stunted growth, chlorosis as well as slow dying of meristems (R a h i m i and B u s s le r, 1973 b). Those species which are 
especially sensitive to copper deficiency (e.g. wheat) additionally show decreased stem stability, resulting most likely from histological alterations. $\mathrm{R} \mathrm{a} \mathrm{h} \mathrm{i} \mathrm{m} \mathrm{i}$ and $\mathrm{B}$ u s s l e r (1973 a) found thinner cell walls in certain tissues and poorer lignification of sclerenchyma cell walls and xylem vessels in several studied species (coleus, sunflower, paprika, oat, tomato).

Copper deficiency causes severe disorders in blooming ( $\mathrm{G} \mathrm{r}$ a h a m, 1975; N a m bia r, 1976; We ry s z o et al., 1983; Unno et al., 1984; A llow a y et al., 1986) and fruition ( $\mathrm{R} \mathrm{u} \mathrm{s} \mathrm{z} \mathrm{k} \mathrm{ow} \mathrm{s} \mathrm{k} \mathrm{a} \mathrm{et} \mathrm{al.,} \mathrm{1983).}$

The conducted studies on the morphology and anatomy of wheat shoots were aimed at finding to what degree was the reaction to $\mathrm{Cu}$ deficiency in the experimental plants manifested in changes in the structure of stemand leaf tissues and of the generative elements of the flower. An attempt was made to answer the following questions:

1. If there is a decrease in the lignification of cell walls, are all lignified tissues equally affected?

2. Can the histochemical test used to evaluate the degree of tissue lignification be used in the early diagnosis of $\mathrm{Cu}$ deficiency in plants?

3. Which traits in the anatomical structure of stems, aside from the degree of tissue lignification, can be responsible for their poorer stability?

The study was carried out on several wheat cultivars and based on several years of experience in pot and field experiments, in cooperation with the Department of Plant Nutrition Physiology of the Institute of Cultivation, Fertilization and Soil Science in Puławy within the framework of Problem CPBR - 3.18.C-9.

\section{MATERIAL AND METHODS}

The pot experiments were carried out on Triticum aestivum L.cv. Alfa while the field experiments in the Babórkowo - near Poznań - Experimental Station used cv. Liwilla, those at the Grabów - near Puławy - Experimental Station used cv. Grana (1987) and Emika (1988).

The substrate in the pot experiments was either Cu-deficient peat or peat + quartz sand at $1.5 \mathrm{~kg}+3.9 \mathrm{~kg}$ per pot. After germination the plants were fed with a solution of $\mathrm{CuSO}_{4}$ providing various $\mathrm{Cu}$ doses; 0,5 or $125 \mathrm{mg} / \mathrm{Mitscherlich}$ pot.

The field experiments were also conducted on soils characterized by $\mathrm{Cu}$ deficiency, adding various doses of this microelement to it: $0 ; 5 ; 10$ or $20 \mathrm{~kg} \mathrm{Cu} / \mathrm{ha}$. The soil in Baborówko was classified as light clay sands on clay, whose agricultural suitability complex was determined as 4 rye, very good. The soil in Grabowo, however, was found to be strong clay sand on clay classified as 2 wheat, good.

The plant material was collected for analysis several times during the vegetation period. Fragments of the stems, leaves and ears were fixed in $70 \%$ ethanol. 
Microscopic slides were prepared from stem and leaf cross-sections and used for observations and measurements. The structures of pistils, anthers and pollen grains of plants supplied with $\mathrm{Cu}$ and growing under conditions of a deficit of this microelement were compared. The phloroglucine $+\mathrm{HCl}$ histochemical test was used to evaluate the degree of tissue lignification. Pollen viability was tested using Belling's solution while its starch content was assayed with Lugol's solution.

\section{RESULTS}

\section{Pot experiments}

\section{Morphologicalobservations}

Shoot growth was inhibited by over $50 \%$ under conditions of acute $\mathrm{Cu}$ deficiency $(\mathrm{Cu}=0)$ as compared with $125 \mathrm{mg} \mathrm{Cu}$ per pot (Plate 1 , Table 1). The stems were significantly thinner and less stable. Also the leaves of $\mathrm{Cu}$-deficient plants were characterized by a smaller size than in plants fertilized with $\mathrm{Cu}$. The youngest leaf blades of $\mathrm{Cu}=0$ plants were white or light green either at their tips or over their entire length, were limp, rolled and gradually withered and died. These plants did not come into ear, small ear primordia remained enclosed in leaf sheaths. At $5 \mathrm{mg} \mathrm{Cu} /$ pot only a few of the plants came into ear.

\section{Stcm an a to my}

In the 1985 experiments the diameter of the Alfa wheat variety under conditions of $0 \mathrm{Cu}$ was $50 \%$ that at $125 \mathrm{mg} / \mathrm{Cu} /$ pot, while in 1986, $66 \%$ (Table 1, Plate 2). Analysis of stem tissues showed that $\mathrm{Cu}$ deficiency significantly inhibited their formation (Table 1). Lignified cell walls were found in epidermis cells at $125 \mathrm{mg} \mathrm{Cu} / \mathrm{pot}$ (Table 2), whereas at $0 \mathrm{Cu}$, these walls remained unlignified and were significantly thinner than in plants supplied with copper. The thickness of the sclerenchyma band under the epidermis decreased due to the reduction of the number of its layers. Very large differences were observed in the thickness of the cell walls of sclerenchyma cells (Plate 3) and in their degree of lignification (Table 2). At $\mathrm{Cu}=0$ these walls were thin and the presence of lignin was not found. $\mathrm{At} \mathrm{Cu}=5 \mathrm{mg} / \mathrm{pot}$, the thickness of these walls increased and various degrees of lignification were observed, even within the same stem section in neighbouring fragments of the sclerenchyma band. The lignification of cell walls was most intense and uniform at the optimal $\mathrm{Cu}$ dose (125 mg/pot).

The decrease in the stem diameter and thickness of the stem wall at $\mathrm{Cu}=0$ were caused mainly by the $30 \%$ decrease in the thickness of the parenchyma. The diameter of parenchyma cells themselves was reduced (by over $20 \%$ ) as well as the number of layers of this tissue. During grain maturation the parenchyma cell walls were lignified at $\mathrm{Cu}=125 \mathrm{mg} /$ pot while at $\mathrm{Cu}=0$, no lignification occurred (Table 2). 
The size of vascular bundles in stems was found to decrease due to acute $\mathrm{Cu}$ deficiency. Our measurements indicate that the length of the radial section of these bundles decreased by about $20 \%$, as did the diameter of metaxylem vessels. The sclerenchyma sheath around the bundles was also found to be of a smaller size. Lignification of cell walls in the xylem and sclerenchyma tracheal elements around the bundles was present, although to a lesser degree than at $\mathrm{Cu}=5$ or $\mathrm{Cu}=125$.

Distinct differences were observed in the degree of tissue lignification in plants supplied with various amounts of $\mathrm{Cu}$. $\mathrm{At} \mathrm{Cu}=0$, the peripheral tissues remained unlignified (epidermis, sclerenchyma, chlorenchyma and parenchyma), xylem and sclerenchyma, elements of vascular bundles, were only slightly lignified. $\mathrm{At} \mathrm{Cu}=5$, various degree of lignification of tissues was found, with moderate lignification prevailing. At $\mathrm{Cu}=125$, however, intense lignification of all of the examined tissues was found.

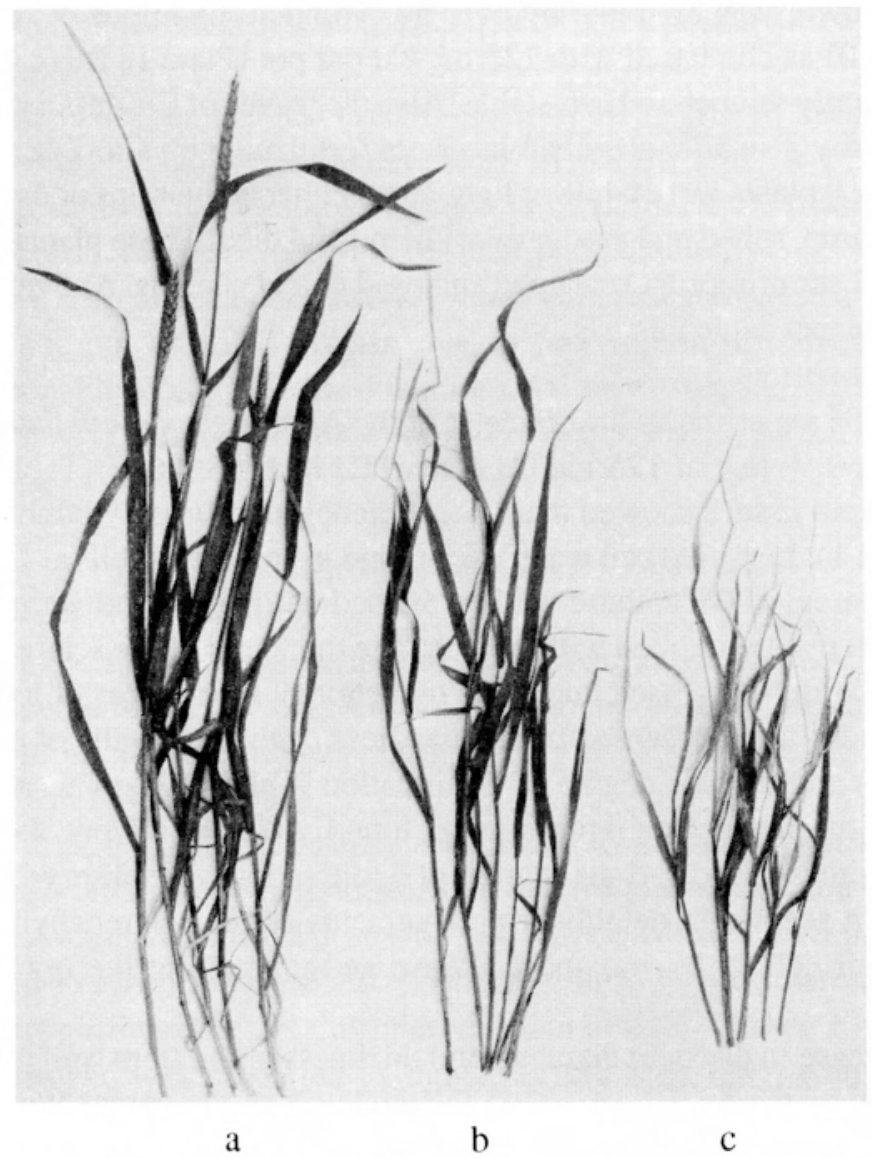

Plate 1. Wheat (cv. Alfa) shoots at various levels of $\mathrm{Cu}$ in the substrate: $\mathrm{a}-\mathrm{Cu}=125 \mathrm{mg} /$ pot, $\mathrm{b}-\mathrm{Cu}=5 \mathrm{mg} /$ pot, $\mathrm{c}-\mathrm{Cu}=0$. 
Le af a natomy

The results of measurements of leaf blade widths of the apical (flag) leaf and the second leaf from the top (subflag leaf) (measured at mid-length) indicate a correlation between the copper content in the soil and leaf breadth. The leaves were the narrowest at $\mathrm{Cu}=0$, while at $\mathrm{Cu}=125$ the leaf blade were widest (Table 5). The main vein thickness and number of vascular bundles were similarly substantially diminished under conditions of copper deficiency. The edges of the leaf blades of plants supplied with different doses of $\mathrm{Cu}$ were compared. It was found that the hook-shaped trichomes growing out of the epidermis were smaller at $\mathrm{Cu}=0$ and had thinner cell walls than at $\mathrm{Cu}=125 \mathrm{mg} /$ pot (Plate 4).
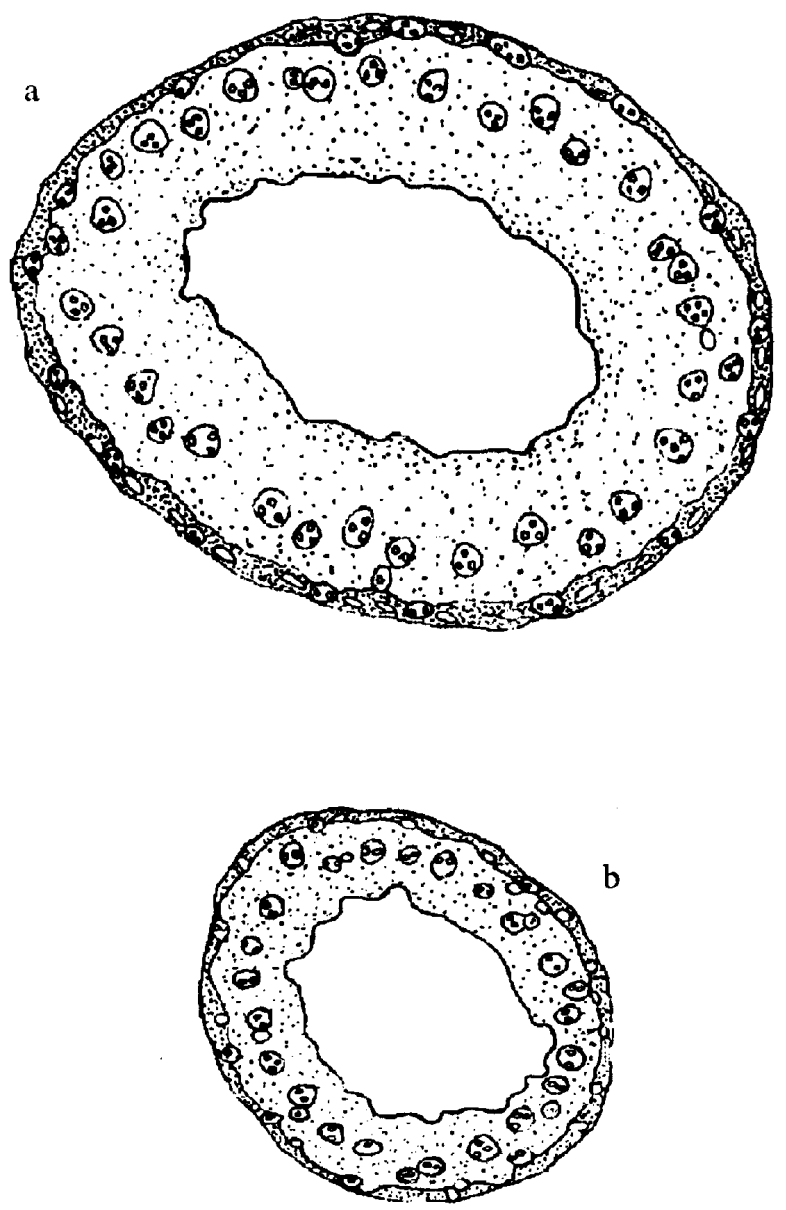

Plate 2. Diagrams of cross-sections through the middle of the third internode of wheat stems (cv. Alfa): $\mathrm{a}-\mathrm{Cu}=125 \mathrm{mg} / \mathrm{pot}, \mathrm{b}-\mathrm{Cu}=0(\mathrm{x} 17.5)$. 

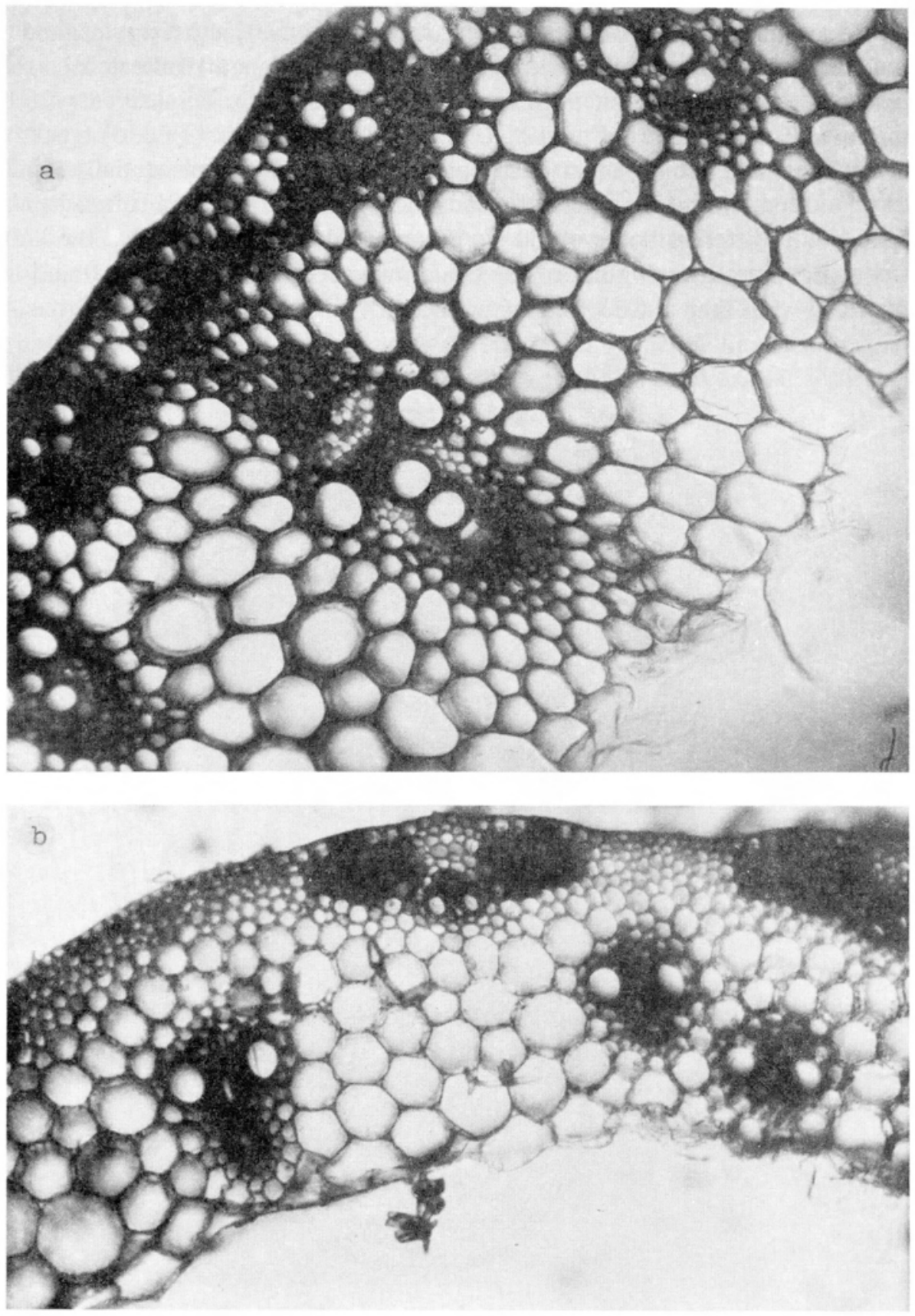

Plate 3. Fragments of cross-sections through the middle of the fourth internode of $\mathrm{cv}$. Alfa wheat stems, wax ripeness stage, at various doses of $\mathrm{Cu}: \mathrm{a}-\mathrm{Cu}=125 \mathrm{mg} /$ pot, $\mathrm{b}-\mathrm{Cu}=0$ (approx. 120x). 

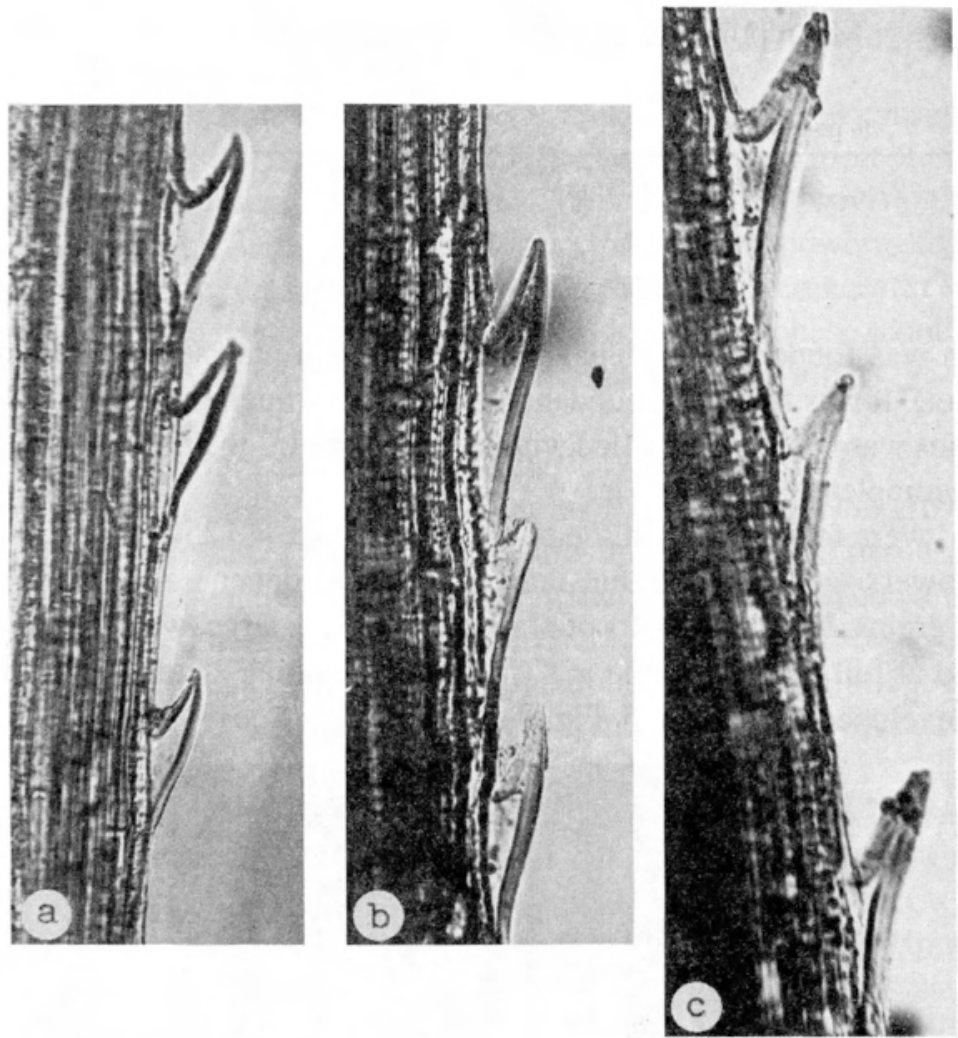

Plate 4. Hook-shaped trichomes on the edge of flag leaves of $\mathrm{cv}$. Alfa wheat at various levels of $\mathrm{Cu}$ : $\mathrm{a}-\mathrm{Cu}=0, \mathrm{~b}-\mathrm{Cu}=5, \mathrm{c}-\mathrm{Cu}=125$ (approx. 300x).

\section{Inflorescences and flowers}

$\mathrm{Cu}$ deficiency had an inhibitory effect that was already visible in the early stages of inflorescence development, significantly delaying their formation (Plate 5). In the material from June 5,1985 , the ear primordia at $\mathrm{Cu}=0$ were only a few millimeters long, at $\mathrm{Cu}=52 \mathrm{~cm}$ long, whereas at $\mathrm{Cu}=125$, advanced development of $8-10 \mathrm{~cm}$ long ears was found.

The experimental plants grown in peat plus sand developed flowers at all studied $\mathrm{Cu}$ doses; those grown in peat only did not come to ear at $\mathrm{Cu}=0$. The inflorescence primordia, whose growth was inhibited, gradually degenerated without having developed flowers. These processes were accompanied by the rapidly progressing during up of plants. The flowers from plants growing under $\mathrm{Cu}$ deficiency were characterized by smaller generative parts - stamens and pistils (Plate 5, Fig. d). The pistils had significantly smaller ovaries, the stamens had smaller anthers. The pollen grains formed in them were deformed, small and lacked viability. The largest, normally developed pollen grains occurred at $\mathrm{Cu}=125 \mathrm{mg} /$ pot. 
Mean pollen dimensions of the Alfa wheat cultivar

\begin{tabular}{lrll}
\multicolumn{2}{c}{ in peat with sand } & \multicolumn{2}{c}{ in peat } \\
\hline $\mathrm{Cu}=0$ & $44.8: 39.3 \mu \mathrm{m}$ & $\mathrm{Cu}=0$ & $\begin{array}{l}\text { no inflorescen- } \\
\text { ces developed }\end{array}$ \\
$\mathrm{Cu}=5$ & $55.1: 47.7 \mu \mathrm{m}$ & $\mathrm{Cu}=5$ & $41.8: 36.3 \mu \mathrm{m}$ \\
$\mathrm{Cu}=125$ & $55.0: 47.5 \mu \mathrm{m}$ & $\mathrm{Cu}=125$ & $54.8: 48.2 \mu \mathrm{m}$
\end{tabular}

Starch was found in the pollen grains formed in plants supplied with copper $(125 \mathrm{mg} / \mathrm{pot})$. It was found in abundant amounts all through the grain. $\mathrm{At} \mathrm{Cu}=5$ the pollen grains were only partly filled with starch (from $1 / 2$ to $2 / 3$ ), whereas at $\mathrm{Cu}=0$, they were completely devoid of it.

Grains were formed only in the peat cultures at $\mathrm{Cu}=125$ (Plate 5, Fig. 5 e). At $\mathrm{Cu}=5$ flowers were formed, but underwent rapid degeneration without having developed grains. In all of the ears of plants at $\mathrm{Cu}=125$, large, well-developed grains were found at full ripeness while at $\mathrm{Cu}=5$, degenerating stamens and pistils were found in developed ears (Plate 5, Fig. 5 e).
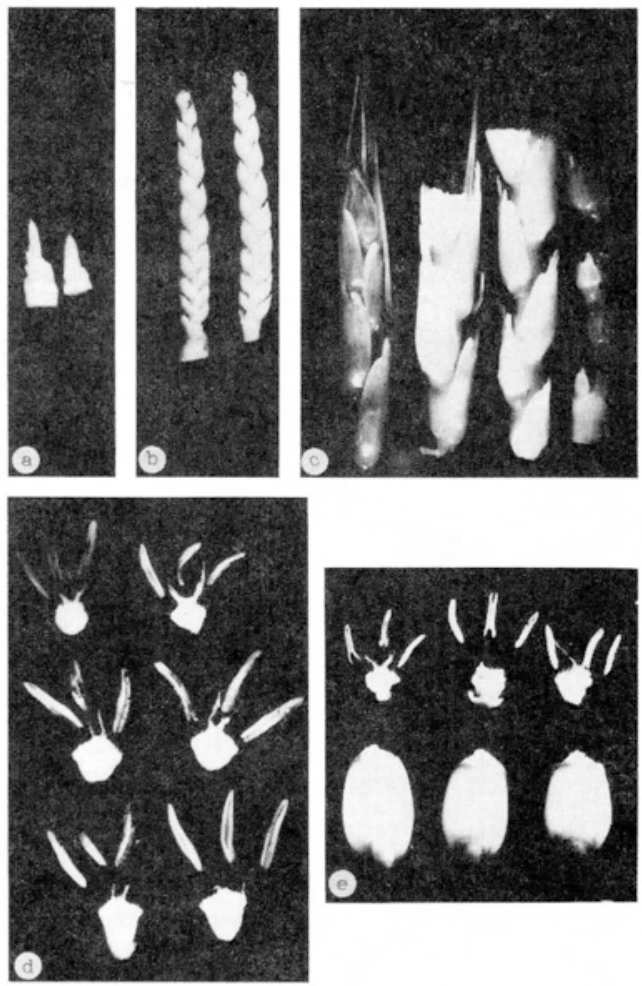

Plate 5. a, b, c - cv. Alfa wheat inflorescence primordia at various levels of $\mathrm{Cu}: \mathrm{a}-\mathrm{Cu}=0, \mathrm{~b}-\mathrm{Cu}=5$, $\mathrm{c}-\mathrm{Cu}=125(1985.06 .05)($ approx 2.5x); d flowers of $\mathrm{cv}$. Alfa wheat at various doses of $\mathrm{Cu}$ : from the top,

$\mathrm{Cu}=0, \mathrm{Cu}=5, \mathrm{Cu}=125$ (approx. $4 \mathrm{x}) ; \mathrm{e}-$ grain from plants provided with copper $(\mathrm{Cu}=125)$ and degenerating flowers under conditions of moderate copper deficiency $(\mathrm{Cu}=5)(1985.07 .31)$ (approx. 4x) 


\section{Field experiments}

Material obtained from field experiments conducted during 3 consecutive years between 1986 and 1988 was used to test if histochemical evaluation of the degree of tissue lignification can be used as a practical indicator of $\mathrm{Cu}$ provision in the early stages of development. Stems from two stages of development were studied: shooting into blade and coming into ear. In the earlier stage, differences in lignification were found only in the lower internodes, whereas in the later phase (coming into ear) differences were also found in the second internode from the top.

B a borów ko- c v. Li willa

Particularly distinct differences in the degree of stem lignification were found between $\mathrm{Cu}=0$ and $\mathrm{Cu}=20 \mathrm{~kg} / \mathrm{ha}$ during the 1987 and 1988 growing season (Table 3). These differences were visible mainly in the peripheral tissues (epidermis, sclerenchyma, photosynthetic and basic parenchyma), and did not occur in the xylem of vascular bundles. The $\mathrm{Cu}=0$ plants were characterized by either lack of lignified peripheral tissues or only their slight lignification, moderate lignification was only very rarely found. In 1986 no variations in tissue lignification were found in the material.

Grabów - cv.: Grana 1986 and 1987 , Emika - 1988.

Differences in tissue lignification occurred in both varieties at the various $\mathrm{Cu}$ levels; the largest differences were found between $\mathrm{Cu}=0$ and $\mathrm{Cu}=20 \mathrm{~kg} / \mathrm{ha}$ (Table 4). The most distinct differences were also observed in the peripheral tissues, none were found in the xylem where the degree of lignification was the same at all $\mathrm{Cu}$ levels and the strongest colour reaction occurred there. Complete lack of lignification at $\mathrm{Cu}=0$ was most often found in the parenchymal tissues, while at $\mathrm{Cu}=20$ these tissues were moderately or highly lignified. In most plants of both varieties lesser degrees of lignification were found in the epidermis and peripheral sclerenchyma at $\mathrm{Cu}=0$. Examination of $\mathrm{cv}$. Grana stems in 1986 did not show any differences in lignification.

\section{DISCUSSION}

The results of this study show that in wheat, $\mathrm{Cu}$ deficit causes inhibition of stem growth, thinner culms with highly restricted lignification and the formation of leaves having thinner and narrower blades. These leaves had a smaller number of veins and smaller epidermal trichomes with thinner cell walls. The occurrence of very large differences between wheat shoots at various levels of fertilization with $\mathrm{Cu}$ was corroborated by the results of experiments conducted at the Department of Plant Nutrition Physiology of the Institute of Cultivation, Fertilization and Soil Science (ICFSS) related to the dry weight of the above-ground parts of cv. Alfa. These studies showed that at $\mathrm{Cu}=0$ (after coming into ear) the shoot weight was 8 times smaller, at $\mathrm{Cu}=5-2.6$ times smaller than at $\mathrm{Cu}=125$ (unpublished data). 
Table 1

Shoot lenght and tissue dimensions on croos-sections of stems of wheat cv. Alfa at various doses of $\mathrm{Cu}$ (beginning of ripening 1985)

\begin{tabular}{|c|c|c|c|c|}
\hline \multirow{2}{*}{\multicolumn{2}{|c|}{$\begin{array}{l}\text { Studied anatomical } \\
\text { and morfological trait }\end{array}$}} & \multicolumn{3}{|c|}{$\mathrm{Cu}$ dose in $\mathrm{mg} / \mathrm{pot}$} \\
\hline & & 0 & 5 & 125 \\
\hline \multicolumn{2}{|c|}{ Shoot lenght $(\mathrm{cm})$} & 42.2 & 72.2 & 91.4 \\
\hline \multicolumn{2}{|c|}{ Stem diameter $(\mu \mathrm{m})$} & 2350.0 & 3208.3 & 3533.3 \\
\hline \multicolumn{2}{|c|}{ Culm wall thickness $(\mu \mathrm{m})$} & 590.0 & 886.2 & 993.7 \\
\hline \multirow{2}{*}{ Sclerenchyma } & Tissue thickness $(\mu \mathrm{m})$ & 118.7 & 125.0 & 128.0 \\
\hline & Number of layers & 4.2 & 4.5 & 4.7 \\
\hline \multirow{3}{*}{ Parenchyma } & Tissue thickness $(\mu \mathrm{m})$ & 631.2 & 793.7 & 927.1 \\
\hline & Number of layers & 12.2 & 13.0 & 14.0 \\
\hline & Cell diameter $(\mu \mathrm{m})$ & 51.7 & 61.0 & 66.2 \\
\hline \multicolumn{2}{|c|}{$\begin{array}{l}\text { Lenght of radial section along } \\
\text { vascular bundles }(\mu \mathrm{m})\end{array}$} & 146.0 & 171.0 & 177.0 \\
\hline \multicolumn{2}{|c|}{$\begin{array}{l}\text { Diameter of metaxylem vessels } \\
\text { in large vascular bundles ( } \mu \mathrm{m})\end{array}$} & 40.0 & 52.0 & 52.9 \\
\hline
\end{tabular}

Table 2

The degree of lignification of particular tissues in wheat stems of $\mathrm{cv}$. Alfa at various $\mathrm{Cu}$ doses in the substrate (beginning of ripening middle of third internode, 1985)

\begin{tabular}{|c|c|c|c|c|}
\hline \multirow{2}{*}{ Tissue } & \multicolumn{4}{|c|}{$\mathrm{Cu}$ dose in $\mathrm{mg} / \mathrm{pot}$} \\
\hline & 0 & & 5 & 125 \\
\hline Epidermis & - & & $+\quad++^{*}$ & ++ \\
\hline Peripheral sclerenchyma & - & & $+\quad++$ & t+ \\
\hline Parenchyma & - & & $+\quad++$ & ++ \\
\hline $\begin{array}{l}\text { Sclerenchyma surrounding } \\
\text { vascular bundles }\end{array}$ & $-\quad+$ & ++ & +++ & +++ \\
\hline Xylem & +++ & ++ & +++ & +++ \\
\hline
\end{tabular}

* - more than one value given for the same level of $\mathrm{Cu}$ is due to the fact that differences were observed in individual plants Histochemical test: floroglucine $+\mathrm{HCl}$

- no lignification

+ slight lignification no colour reaction pink
+ moderate lignification

++ inten se lignification light cherry red dark red 
Table 3

The degree of lignification of particular tissues in wheat stems of $\mathrm{cv}$. Liwilla at various $\mathrm{Cu}$ doses in the substrate (coming into ear, middle of third internode, 1987 and 1988)

\begin{tabular}{|c|c|c|c|c|}
\hline \multirow{2}{*}{ Tissue } & \multicolumn{4}{|c|}{$\mathrm{Cu}$ dose in $\mathrm{mg} /$ pot } \\
\hline & 0 & 5 & 10 & 20 \\
\hline Epidermis & $\begin{array}{c}+ \\
++\end{array}$ & $\begin{array}{c}+ \\
++\end{array}$ & $\begin{array}{c}+ \\
++\end{array}$ & $\begin{array}{c}++ \\
+++\end{array}$ \\
\hline Peripheral sclerenchyma & $\begin{array}{l}- \\
+ \\
++\end{array}$ & $\begin{array}{c}+ \\
++\end{array}$ & $\begin{array}{c}+ \\
++\end{array}$ & ++ \\
\hline Chlorenchyma & - & - & - & $\dot{-}$ \\
\hline Parenchyma & $\dot{+}+$ & $\dot{+}+$ & + & ++ \\
\hline $\begin{array}{l}\text { Sclerenchyma surrounding } \\
\text { vascular bundles }\end{array}$ & ++ & $\begin{array}{c}++ \\
++ \\
++\end{array}$ & $\begin{array}{c}d+ \\
++\end{array}$ & $\begin{array}{c}++ \\
+++\end{array}$ \\
\hline Xylem & +++ & +++ & +++ & +++ \\
\hline
\end{tabular}

Explanations as in Table 2

Table 4

The degree of lignification of particular tissues in wheat stems of $\mathrm{cv}$. Emika and Grana at various $\mathrm{Cu}$ doses in the substrate (coming into ear, middle of third internode)

\begin{tabular}{|c|c|c|c|c|c|c|c|c|}
\hline \multirow{3}{*}{ Tissue } & \multicolumn{4}{|c|}{ Grana 1987} & \multicolumn{4}{|c|}{ Emika 1988} \\
\hline & \multicolumn{8}{|c|}{ Cu dose in $\mathrm{mg} / \mathrm{pot}$} \\
\hline & 0 & 5 & 10 & 20 & 0 & 5 & 10 & 20 \\
\hline Epidermis & $\begin{array}{c}+ \\
++ \\
+++\end{array}$ & +++ & +++ & +++ & $\begin{array}{c}+ \\
++\end{array}$ & +++ & +++ & +++ \\
\hline Peripheral sclerenchyma & $\begin{array}{c}+ \\
++\end{array}$ & ++ & ++ & ++ & $\begin{array}{c}+ \\
++\end{array}$ & ++ & ++ & ++ \\
\hline Chlorenchyma & - & + & + & $\begin{array}{c}+ \\
++\end{array}$ & $\overline{+}$ & $\begin{array}{c}- \\
+ \\
++\end{array}$ & $\begin{array}{c}- \\
+ \\
++\end{array}$ & $\begin{array}{c}- \\
+ \\
++\end{array}$ \\
\hline Parenchyma & 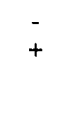 & $\begin{array}{c}+ \\
++\end{array}$ & $\begin{array}{c}+ \\
++\end{array}$ & $\begin{array}{c}+ \\
+ \\
++\end{array}$ & $\begin{array}{c}- \\
+ \\
++\end{array}$ & ++ & $\begin{array}{c}+ \\
++\end{array}$ & +++ \\
\hline $\begin{array}{l}\text { Sclerenchyma surrounding } \\
\text { vascular bundles }\end{array}$ & $\begin{array}{c}++ \\
+++\end{array}$ & +++ & +++ & +++ & $\begin{array}{c}+ \\
++\end{array}$ & $\begin{array}{c}++ \\
+++\end{array}$ & $\begin{array}{c}++ \\
+++\end{array}$ & +++ \\
\hline Xylem & +++ & +++ & $+t+$ & +++ & +++ & +++ & +++ & +++ \\
\hline
\end{tabular}

Explanations as in Table 2 
Table 5

Measurements of leaf blades in cv. Alfa wheat at various levels of $\mathrm{Cu}$ in the substrate (blooming stage, 1985)

\begin{tabular}{|c|c|c|c|c|}
\hline \multirow{2}{*}{\multicolumn{2}{|c|}{ Studied trait }} & \multicolumn{3}{|c|}{$\mathrm{Cu}$ dose in $\mathrm{mg} / \mathrm{pot}$} \\
\hline & & 0 & 5 & 125 \\
\hline \multirow{2}{*}{ Leaf blade breadth (mm) } & Flag & 15.5 & 18.5 & 20.5 \\
\hline & Subflag & 7.8 & 14.2 & 15.4 \\
\hline \multirow{2}{*}{ Thicknees of main vein $(\mu \mathrm{m})$} & Flag & 367.7 & 337.2 & 423.7 \\
\hline & Subflag & 527.8 & 718.9 & 800.8 \\
\hline \multirow{2}{*}{ Number of vascular bundles } & Flag & 54.0 & 60.0 & 65.0 \\
\hline & Subflag & 40.5 & 51.0 & 51.0 \\
\hline
\end{tabular}

Examination of the wheat stems provided that under conditions of $\mathrm{Cu}$ deficit, the lignification of cell walls in peripheral tissues (epidermis, sclerenchyma, and basic parenchyma) does not occur or is significantly lower. This in contrast to xylem vessels and the sclerenchyma sheath around the vascular bundles, where lignification occurs either to a slightly smaller extent or to one similar to that when $\mathrm{Cu}$ is supplied. R a h i m i and B u s s le r (1973 a) have, however, found lack of lignification or only small amounts of lignin in the sclerenchyma cell walls and xylem vessels in several studied species. These authors discuss the possibility of inhibition of lignin synthesis under conditions of $\mathrm{Cu}$ deficitdue to a decrease in polyphenol oxydase activity or amount - this enzyme contains $\mathrm{Cu}$ and participates in lignin biosynthesis.

R a h i m i and B u s s l e r (1973 a) suggest the possibility of using the test for the presence of lignin in the cell walls of higher plants for the early diagnosis of $\mathrm{Cu}$ deficiency. Our study on wheat showed that this test may be used in cases of severe (pot experiments) and moderate (field experiments) Cu deficiency as early as the shooting into blade stage, but only in respect to the lowest internodes where lignification of tissues is most advanced. In the later stages of development, however (e.g. coming into ear), internodes from higher positions may be compared.

The results of the field study reported here on the degree of lignification of wheat tissues correlate with data on the grain yields for the particular varieties from the Institute for Fertilization of the ICFSS (unpublished data). It results from them that in 1986 the differences in the yields at various levels of copper were statistically insignificant in the case of cv. Grana (Grabów) and Liwilla (Baborówko). Significant differences in the lignification of the tissues in the stems of these plants also were not found that year. In 1987 and 1988, however, the yields of Liwilla and in 
1988 of Emika, were significantly decreased at $\mathrm{Cu}=0$, which was confirmed statistically. Significant differences in tissue lignification were found in the experimental material from these growing periods.

The decreased stability of wheat stems was, in addition to lignification, caused by the following changes arising from Cu deficiency: decreased stem diameter and decreased culm thickness due to reduced thickness of the sclerenchyma band and parenchyma (brought about by a reduction in the number of cells layers and cell diameters), decreased wall thickness of the epidermis and sclerenchyma, formation of smaller vascular bundles and xylem vessels with a smaller diameter, decrease of the sclerenchyma sheath around the vascular bundles. The diminishment of cell wall thickness is probably related to limited cellulose synthesis in plants grown under conditions of $\mathrm{Cu}$ deficit. This is also indicated by the results of studies conducted by Ś l u s a r c z y k and R u s z k ow ska (1986) on oat shoots growing under a Cu deficit. These authors found decreased amounts of cellulose, hemicellulose and soluble sugars in the experimental plants. Following the disturbances in the development of the vegetative parts, abnormalities in the generative phase occurred as well. In extreme cases, plants did not develop ears because of premature degeneration of primordia. If inflorescences and ears were formed, they were much smaller than in plants supplied with copper and produced small, deformed, unviable pollen grains that were devoid of starch. These flowers wilted and died relatively rapidly, without having produced grains. Several authors have investigated the reasons why unviable pollen grains are formed when Cu is lacking. $\mathrm{G} \mathrm{r} \mathrm{a} \mathrm{h} \mathrm{a} \mathrm{m}$ (1975) reports that the sterility of pollen in wheat is determined by disturbances in meiosis or results from the lack of starch accumulation in these grains. U n n o et al. (1984) corroborate Graham's hypothesis (1975) and state that it is the lack of starch in pollen grains that leads to its sterility.

In this study too, a lack of starch in wheat pollen grains at acute $\mathrm{Cu}$ deficiency $(\mathrm{Cu}=0)$ was found, whereas at moderate deficiency $(\mathrm{Cu}=5)$, smaller amount of starch were discovered, accumulated in $1 / 2$ to $2 / 3$ of the capacity of the grain. A $110-$ w a y et al. (1986) observed normal microsporogenesis in the anthers of barley, but found hypertrophy of the tapetum which enveloped the developing pollen grains, stifled them and thus caused their sterility. The abnormalities in flower structure and the problem of pollen sterility due to $\mathrm{Cu}$ deficiency are still not fully understood and studies in this field are being continued.

\section{SUMMARY}

1. Under conditions of $\mathrm{Cu}$ deficiency, a reduction in the length and stability of wheat stems occurred due to the reduction of their diameter and wall thickness of the 
blade, poorer development of particular tissues (smaller cells, fewer layers), but mainly due to the reduction in the degree of lignification of peripheral tissues (epidermis, sclerenchyma, parenchyma) and formation of thinner cell walls in the epidermis and sclerenchyma.

2. The histochemical test used to determine the degree of lignification of stem tissues may serve in the diagnosis of Cu provision in wheat as early as in the shooting into blade stage, but only in the lowest internodes where the lignification of tissues is advanced. However, in the coming to ear stage, the internodes in higher positions may also be compared.

3. Under conditions of $\mathrm{Cu}$ deficit, the following were found in wheat leaves: chlorosis, wilting, rolling, dying of the apical parts of the youngest leaves, decreased thickness and width of the leaf blade of the flag and subflag leaves. The number of vascular bundles in these leaves was also reduced. Smaller hook-shaped trichomes were observed in the epidermis. The cell walls of these trichomes were significantly thinner than in plants provided with copper.

4. The inflorescences and flowers formed under conditions of copper deficit were stunted in their development, were smaller and rapidly underwent degradation processes. The stamens produced smaller, deformed and sterile pollen, no fruits were developed.

\section{REFERENCES}

A ll ow a y B. J., Je we 11 A.W., Mur ray B.G., 1986. Effects of subclinical copper deficiency on pollen development and yield in cereals. Second Intern. Symp. on the Role of Micronutrients in Agriculture. Toulouse, ISAMA Publ. P. Morard.

G r a h a m R. D., 1975. Male sterility in wheat plants deficient in copper. Nature (Lond.) 254: 514-515.

$\mathrm{N} \mathrm{a} \mathrm{m} \mathrm{b} \mathrm{i} \mathrm{a} \mathrm{r} \mathrm{E.} \mathrm{K.} \mathrm{S.,} \mathrm{1976.} \mathrm{Genetic} \mathrm{differences} \mathrm{in} \mathrm{the} \mathrm{copper} \mathrm{nutrition} \mathrm{of} \mathrm{cereals.} \mathrm{I.} \mathrm{Differential} \mathrm{Responses} \mathrm{of}$ Genotypes to Copper. Aust. J. Agric. Res. 27: 453-463.

R a h i m i A., B u s s l e r W., 1973 a. Die Wirkung von Kupfermangel auf die Gewebestruktur höherer Pflanzen. Z. Pfl. Ern. Bodenk. 135 (3): 183-195.

R a h i m i A., B u s s le r W., 1973 b. Die Diagnose des Kupfermangels mittels sichtbarer Symptome on höheren Pflanzen. Z. Pfl. Ern. Bodenk. 135 (3): 267-283.

Ruszkowska M., Eyszcz S., SIusarczyk M., Wojcieska U., Wolska E., Zienkie. w i c z E., 1983. Badania nad fizjologiczną rolą miedzi w plonowaniu roślin zbożowych. Zesz. Probl. Post. Nauk. Rol. 242: 167-176.

S l u s a r c z y k M., R u s z k ow ska M., 1986. The effect of copper on the content and composition of sacharides in oat plants. Acta Agrobot. 36 (2): 261-276.

Unno Y., Dobas h i K., M i zu no N., 1984. Interaction between starch accumulation in pollen and sterility of wheat, barley and rye on a copper deficient soil. J. Sci. Soil Manure, Japan, 55: 495-498.

Weryszko E., Ruszkowska M., Tomas zewski A., 1983. Zmiany w budowie kwiatów i kwiatostanów owsa (Avena sativa L.) w warunkach niedoboru miedzi. Acta Agrobot. 36 (1-2): 49-57. 


\title{
Anatomiczne i morfologiczne wskaźniki zawartości miedzi w pszenicy (Triticum aestivum L.)
}

\author{
Streszczenie
}

Badano wpływ niedoboru miedzi na morfologię $\mathrm{i}$ anatomię pędów pszenicy (Triticum aestivum L.) stosując różne dawki Cu: 0, 5 i $125 \mathrm{mg} /$ wazon Mitscherlicha na podłożu z deficytem tego pierwiastka. Stopień zdrewnienia tkanek lodygi badano również w materiale $\mathrm{z}$ doświadczeń polowych przy różnych poziomach $\mathrm{Cu}: 0,5,10$, $20 \mathrm{~kg} / \mathrm{ha}$. Stwierdzono, że przy niedoborze miedzi wystąpiły znaczne zmiany morfologiczne $\mathrm{i}$ anatomiczne w lodydze i liściach oraz zahamowanie rozwoju kwiatostanów i kwiatów. W pręcikach powstawały zdeformowane i sterylne ziarna pylku. Zmniejszoną stabilność lodyg powodowaly: znaczna redukcja średnicy lodygi i grubości ścian źdźbla, zmniejszenie liczby warstw i wielkości komórek sklerenchymy oraz miękiszu, ograniczenie wielkości wiązek przewodzących i średnicy naczyń ksylemu oraz zmniejszenie pochwy sklerenchymatycznej wokól wiązek. W komórkach epidermy i sklerenchymy występowały cieńsze ściany. W tkankach obwodowych (epiderma, sklerenchyma, miękisz) najczęściej obserwowano brak lignifikacji ścian komórkowych. Nie stwierdzono wyraźnych różnic w zdrewnieniu ścian naczyń ksylemu i sklerenchymy wokółwiązkowej. Wykazano, że nie istnieje możliwość praktycznego zastosowania testu histochemicznego do badania stopnia zdrewnienia lodyg we wczesnych fazach rozwoju pszenicy. 